\title{
COMPARATIVE STUDY OF ADULTHOOD: THE CASE STUDIES OF UNIVERSITY STUDENTS AND STUDENTS OF VOCATIONAL TRAINING ON THE ISLAND OF LEMNOS, GREECE
}

\author{
Sofia Arvanitidou' ${ }^{1 i}$, \\ Eugenia Arvanitis ${ }^{2}$ \\ ${ }^{1}$ Deputy Director, \\ Vocational Training Institute, \\ Lemnos, Greece \\ ${ }^{2}$ Associate Professor Dr., \\ Interculturality \& Diversity in Education, \\ University of Patras, \\ Greece
}

\begin{abstract}
:
A comparative study of adulthood was conducted to explore the levels of self-esteem and the parameters of adulthood among students at the Aegean University, Department of Food Science and Nutrition (D.F.S.N.) and the students of public Institute of Vocational Training (Greek: IEK), both located on the Greek island of Lemnos. Thus, maturity, responsibility, autonomy, self-management and the sense of social responsibility were measured on a Likert scale and Rosenberg's self-esteem scale. The research investigated whether being a student of Tertiary Education or a student of Vocational Training has an effect on the concept of adulthood or influences the level of individual self-esteem. The quantitative results brought to light that adulthood can be attained without direct relevance to the Educational Institute whereas the degree of self-esteem and selfmanagement in women was determined to some extent by the choice of School. This conclusion has raised issues of major importance for further research.
\end{abstract}

Keywords: adulthood, tertiary education, vocational students, university students, selfesteem

\section{Introduction}

This article analyzes adulthood through the lens of maturity, responsibility, autonomy, self-management and sense of social responsibility. It also explores the interconnection of these characteristics with self-esteem. A comparison is also made between a sample of university level students and students from a vocational training institute.

iCorrespondence: email sofia.arvanitidou@gmail.com 
The purpose of this study is to investigate whether there is a difference between university students and vocational training students in the attainment of adulthood and self-esteem. The study of adulthood was carried out by highlighting the self-esteem levels of adult learners and by measuring the particular characteristics of adulthood (maturity, responsibility, autonomy, self-management and sense of social responsibility). The sample consists of students of tertiary education compared to the students of the public Institute of Vocational Training (Greek: IEK).

Merriam, Caffarella, and Baumgartner (2007), analyze the concept of adulthood through four basic approaches to adult development: the biological approach focuses on the "impact of developmental nature (physical age, environment, health) whereas the psychological approach is based on a deep understanding of the internal processes that determine human behavior" (pp. 298-324). The sociocultural approach emphasizes that the individual's development is directly influenced by the socio-cultural context. Finally, the "integrative approach" (Merriam et al., 2007, pp. 298-324) is used to examine how the biological, psychological and socio-cultural aspects of adult development intersect and influence each other. The authors argue that to fully understand the development of adult learners, the human mind should be open to multiple interpretations of what adulthood is and whether it affects the learning process positively or negatively.

Equally important for acquiring adulthood is the investigation of the social responsibility of adult learners. The skill of social responsibility can be described as the skill that makes it possible to understand the social reality in which we live, so we can improve it. Among the skills that adult learners acquire to be socially responsible are communicating in different contexts, expressing ideas but also listening to the opposite view and understanding a situation from a different perspective; hence, they can, most importantly, make decisions at different levels of social life and can evaluate individual and group interests (European Commission, 2019). The skill of social responsibility also entails the ability to overcome differences while maintaining mutual respect (European Commission, 2004c).

The present work is divided into three parts. The first part presents an overview of international literature on the concepts of Adulthood and Self-esteem within the adult education literature. The study's theoretical framework illuminates the characteristics of adult learners, the obstacles encountered during the learning process, aiming at categorizing the students of higher education and the students of Vocational training as Adult Students. The second part addresses the research. The methodological approach (quantitative), sampling method, the data collection tools (questionnaires, the Rosenberg self-assessment scale), and the stages of the research as well as the method of analyzing and processing data are described. The descriptive research design of this study is analyzed through quantitative methods. Conclusions and the research constraints are presented in the last part of the study together with the proposals for future studies based on the findings of this research. 


\section{The concepts of Adulthood and Self-esteem in Adult Education}

When analyzing the concept of adulthood, it is important to consider the criterion of selfmanagement as directly related to self-regulation, but also as one of the psychosocial factors (Monahan et al., 2009) that affect maturity. Self-regulation involves the monitoring and management of cognitive processes, as well as awareness of emotions, motivations, behaviors in the learning environment (Lauermann \& Karabenick, 2013). Learning how to learn is a developmental process in which awareness, adaptation, and change can promote further understanding and abilities (Merriam \& Bierema, 2014). Motivated to learn, adults engage more deeply in content. Independent, they readily work through lessons with real-world practicality and even influence their direction (Ross-Gordon, Rose \& Kasworm, 2017).

According to Bradberry and Greaves (2003), self-management is related to the management of impulses and dispositions of the adult learner, as well as the handling of relationships by developing social awareness skills. A balance must be struck between the rules of the educational framework and the learner's responsibility in constructing a personal meaning (DelleFave, Wissing, Brdar, Vella-Brodrick, \& Freire, 2013). Wang, Bain, Hansman and Hope (2017), in their attempt to explore the relationship between autonomy and self-management, contend that since the learner's autonomy is likely to vary from situation to situation, adult educators or leaders, should not assume that because a person was self-directed in a situation, he can also succeed in a new one. Subsequently, self-direction requires autonomy but often the meanings of self-concept, motivation and self-directed learning, overlap. Additionally, many scholars agree that self-concept has a positive impact on achievement and success (Rosen, Glennie, Dalton, Lennon \& Bozick, 2010).

Many scholars (Papadopoulou, 2013; Kernis \& Goldman, 2006b, Weinstein, Ryan \& Deci, 2012) often use the term healthy self-esteem to emphasize the distinction between those who may exhibit signs of self-esteem but actually cover their feelings of inadequacy and those who truly possess the characteristics of self-esteem. A crucial element of healthy self-esteem is to have realistic and clear concepts of oneself. In addition, it is obvious that the development of self-esteem is strongly influenced by the experiences of adult learners, which in turn affects their learning. Students with high self-esteem tend to face difficult situations as challenges to overcome rather than as threats to be avoided (Bandura, 1997). Therefore, they try to exercise control over various complicated and hard tasks or situations (Kaliris \& Sidiropoulou-Dimakakou, 2012).

However, according to a plethora of researchers (Jarvis, 2004; Freire, 1982; Knowles, 1990; Mezirow, 1991, etc.) the dominant issue is the empowerment of learners through their "active participation in the educational process and the critical reflection of their experiences" (Kokkos, 2008, p. 76). In particular, the theory of transformative learning developed by Mezirow (1991) can be seen as an evolution of other theories according to which "the process of critical thinking and self-reflection is the most important learning experience in adult life and that its reinforcement should be the primary goal of Adult Education" 
(p. 177). According to Strong, Wynn, Irby, and Lindner (2013), critical thinking is an integral component of self-directed learning which allows learners to play a larger part in the planning of the learning process (Czabanowska, Moust, Meijer, Schroder-Back, \& Roebertsen, 2012). Moreover, Freire (1982) advocates for education that "develops students' consciousness of their rights along with their critical presence in the real world" (p.10). However, compared to Freire's critical view of education aiming for social empowerment and change, Mezirow's approach appears to be more individualistic.

Hence, it has been established that as far as adult learning is concerned, there is no complete consensus of opinion (Rogers, 2002). However, in the last few years, there has been some degree of convergence among experts in terms of the underlying principles of learning. The first point of convergence illustrates the importance of the model of active participation of adults in the learning process as opposed to the knowledge transmission model identified by Freire as "banking education where students are simply filing and storing the deposits" (Freire, 2000, p. 58). The second point of convergence is that learning interacts with the learner's identity, and the third point is that learning engages with the learner's lifeworld experience and acts as an agent of personal and cultural transformation (Kalantzis \& Cope, 2005). The use of experience as an essential component of learning is the point of convergence of many scholars who underline the importance of the adult learners' experiences in strengthening self-esteem and self-identification.

Adult Education (formal, non-formal and informal) can "contribute to improving basic skills, acquiring new skills and upgrading the skill level for employment and personal development" (European Commission/EACEA/Eurydice, 2015, p. 71). Thus, it becomes evident that Adult Education is life-wide since it includes all categories of Education (formal, non-formal and informal) and aims both at the active participation of adult learners in the learning process and in acquiring new skills. In order to achieve this goal, the European Commission is committed to helping all EU countries to develop Adult Education systems that are characterized by flexibility, high quality, excellent teaching and, involvement of local authorities, employers, social partners and cultural organizations.

\subsection{Characteristics of Vocational and Tertiary Institutions in Greece}

In Greece, all universities are publicly owned and funded having state-accredited university title and authorization of university degree awarding powers at level 6 (first cycle qualification, bachelor's level) under the Bologna Process and the National Qualification Framework of Greece which is officially named Hellenic Qualification Framework (EOPPEP, 2016).

Within Greece, big regional differences in tertiary attainment exist, "ranging from over $50 \%$ in Attica (which includes Athens) to $25 \%$ in the southern Aegean. Foreign-born students are much less likely to obtain Higher Education degrees than native-born students (11.9 \% vs $47.1 \%$ ) - the biggest gap in the EU" (European Commission, 2018, p. 129). At $43.3 \%$ in 2016, the share of tertiary graduates working in jobs that do not require a higher education qualification was higher than elsewhere in the EU (EU average: $26 \%$ ) 
(European Commission, 2018). While the difficult macro-economic environment partly explains the high degree of mismatches, there is also a need to create stronger links between labour market needs and education. This includes well-functioning skills forecasting which feeds into VET and university curricula (OECD, 2017a). According to a recent study, main policy challenges include: to increase the attractiveness of VET; to re-orientate from preparing graduates for the public sector to towards the private sector; and to upskill the unemployed (Foundation for Economic and Industrial Research, 2018).

According to the European Centre for the Development of Vocational Training (Cedefop, 2014a), the aims of the Public Vocational Training Institute (V.T.I.) (I.E.K. in Greek language) are:

a) to offer any type of vocational training, either initial or continuing;

b) to provide the trainees with the appropriate qualifications through imparting scientific, technical, professional and practical knowledge;

c) to enable them to develop relevant skills so that their professional integration into society is facilitated and their adaptation to the changing needs of the productive process is ensured.

Vocational Training Institutes in Greece constitute part of Post-secondary compulsory education and can lead to the acquisition of recognized certificates (General Secretariat for Lifelong Learning, 2013). Vocational students attend compulsory theoretical, laboratory and mixed courses. During training, the assessment of learners is attained both by conducting mid-term exams during the semester and by conducting final examinations at the end of the semester. Students, who successfully complete their training at the Public V.T.I., receive a Diploma of Vocational Training (educational level 05). After completing the course and obtaining the diploma, trainees from the public I.E.K. can follow a work placement and they are eligible to sit for biannual National Accreditation Examinations, both in written and oral form. The names of successful candidates in each examination are published on the EOPPEP (National Organization for the Certification of Qualifications and Vocational Guidance) website.

For Greek vocational students, the national strategic framework for VET is in place but ensuring the attractiveness of the sector remains a challenge. The proportion of students in upper secondary VET in Greece remains stable at around $30 \%$, but is far below the EU average (47.3\%) (European Commission, 2018). The employment rate of recent VET graduates remains much lower than the EU average of $76.6 \%$, and well below the total employment rate in Greece (56.2\%), despite having increased to $40.7 \%$ in 2016 (European Commission, 2018). According to the registry of the Public Vocation Training Institute of the Municipality of Lemnos, where the survey is conducted, the majority of the learners are between 18 and 28 years old and the number of admissions has a limit of thirty students in each specialty (hairdressing, cooking and, oenology). Vocational curricula generally include both school-based and work-based learning. Integrating practices and different forms of knowledge are usually considered essential for the development of vocational competence (Mikkonen, Pylväs, Rintala, Nokelainen \& Postareff, 2017; Tynjälä, 2013). 


\subsection{University and Vocational Students as Adult learners}

Some researchers (Rogers, 2002; Kokkos, 2005) have argued that Tertiary Education is part of formal education and does not follow the principles of Adult Education. Within this scope, university students are "adults but in the early (emerging) adulthood, meaning that they share many characteristics of minors, such as the lack of autonomy and the formation of personal and social identity" (Taylor \& Pettit, 2007, pp. 312-31; Jarvis, 2004, pp. 51-54). As Knowles points out, in universities, the adult facilitator often treats the learners as if they were children: "The facilitator has the ultimate responsibility to decide what will be taught, how it will be taught, when it will be taught, and whether it has been assimilated" (1998, pp 61-62). Thus, it is instrumental for the adult educator to "equip adults to effectively engage in the world through individual and collective actions within the spheres of family, work, and community" (Kasworm, Rose \& Ross-Gordon, 2010, p. 4) and, at the same time, promote students' multicultural awareness and social skills (Carson \& Domangue, 2013).

Nevertheless, it is widely accepted that current students are more mature than students of the past (Halx, 2010). This is because they live "in multiple worlds and negotiate the sense of self and meaning based on multiple realities" (Kasworm, 2003, p. 96, as cited in Halx, 2010). Even secondary education students are attaining adulthood earlier than in previous decades. Continuous examinations, subject choices, and the obligation to plan and organize their future studies, prompt young people to take on responsibilities from a very early stage. These responsibilities were the main reason that compels them into becoming mentally ready and empirically mature to meet the expectations of adulthood in tertiary education. Besides, enrolling in a university is usually voluntary, a basic feature of Adult Education. Although there are students entering University "on the basis of exogenous pressures, such the worry about lack of employment opportunities and their parents' expectations, yet most of them are staying and completing their studies by their own choice" (Halx, 2010, p. 522 ). Nevertheless, it is widely known that even those who are described as adults do not always share the characteristics of adulthood and "sometimes behave in a way that is similar to the way of minors" (Rogers, 2002, pp. 60-64). This means that they often renounce their responsibilities, overestimate or underestimate themselves and lack selfmanagement skills. Therefore, these individuals as adult learners are not likely to adopt behaviors that may lead to self-actualization (Krems, Kenrick, \& Neel, 2017).

Additionally, it is worth noting that the new pedagogical example supports the empowerment of students and their encouragement towards autonomy and self-directed learning (Bowman, 2010b). The university becomes an educational environment in which teaching highlights the importance of experience in making meaning, and hence learning. Knowles, Holton, and Swanson (2015) note that adult students "learn new knowledge, understandings, skills, values, and attitudes most effectively when they are presented in the context of application to real-life situations" (p. 46).

Subsequently, it is presumed that Adult Education has been intertwined with the development of social competences, promoting the autonomy of adult learners and the strengthening of their self-esteem. Numerous researches have investigated the relationship between high self-esteem and positive attitude towards life, as the main 
reasons that lead to academic achievements, professional opportunities, popularity, health, happiness and compliance with laws and social codes. Self-fulfillment needs are placed at the highest level of Maslow's pyramid of needs and are related to the desire of an adult learner to feel competent and achieving his/her full potential. This is the stage where the highest possible self-actualization, creativity and, self-expression of the adult learners is achieved (Krems, Kenrick, \& Neel, 2017). Learning, therefore, stems from the actions the learners themselves take, through the use of learning strategies aiming at both personal and social development.

Hence, Rogers's ascertainment (2002) that being an adult is not defined by age but whether a learner has attained adulthood is shared by many Adult Education scholars (Jarvis, 1983; Knowles, 1998; Rogers, 1971; Tight, 2002, etc.). The criterion of selfmanagement as a fundamental criterion for the attainment of adulthood is considered to play a decisive role since many University students in Lemnos and students of Vocational Training are working part-time to finance their studies. Concurrently, many researchers (Gonçalves, 2011; Gorsky, Caspi, \& Tuvi-Arad, 2004), argue that it would be useful for the University to provide opportunities to students by encouraging an exchange of different views. It is through the use of dialogue that students are "forced to leave the convenient area of constructed knowledge and engage in serious critical processing and negotiation of prevailing perceptions" (Kreber, 2009, pp. 3-17).

It is worth mentioning that the present comparative study of adulthood was carried out between the University students and those of the Institute of Vocational Training in Lemnos, taking into consideration students working alongside their studies, and, thus, succeeding in meeting their economic and social obligations. These students seem to possess the required self-determination and self-management, emotional maturity and self-control which they demonstrate through learning processes. The New Education of Values as defined by the UNESCO Report (2011) is based on the development of a series of values that encourage self-awareness, responsibility, initiative, teamwork, collaboration, and self-action. This kind of education "connects development with human evolution and respect for the variety of traditions and cultures" (Christodoulou, 2012, p.11).

Vocational students compared to university ones, strongly believe that the vocational institute is a preparation for work because it aims to ensure readiness to enter the workplace by providing the basic vocational skills needed in work tasks and also by conveying general knowledge about working life, such as employees' rights and obligations (Rintala \& Nokelainen, 2019); hence, they seem focused on workforce skills development. Nevertheless, the role of vocational school and education is, often, experienced as unclear, distant or poorly aligned with workplace experiences. In addition, many vocational students experience that apprenticeship training requires selfstudy, whereas some think that it is mainly independent work that especially provides work specific skills obligations.

In Greece vocational education and training (VET) compared to tertiary education often seemed incomplete and disorganized and as a result it was almost always a second 
choice. Moreover, there were significant structural weaknesses such as low attractiveness, high school drop-out rates, discontinuity and lack of focus on policy design and implementation, large percentage of disappointed and often frustrated teachers, and unclear connection of VET with the labour market (Cedefop, 2019). However, there was ground on which to support VET upgrade, such as the technical equipment and infrastructure and highly qualified teachers Furthermore, a strong incentive to improve VET was the fact that it is chosen by a large percentage of students with social, economic and family problems, with learning difficulties, low self-esteem or low expectations. Keeping in mind, firstly the existing strengths, the wish to support those in need of help and finally the economic and social crisis that started tormenting Greece a decade ago, the Greek Ministry of Education drew up a detailed Strategic Plan for VET in 2016 with a view to upgrading vocational education and training thus responding to the need for economic recovery and paving the way to reducing unemployment (Cedefop, 2019)

The shift towards strengthening development policies constitutes the only way ahead for Greece to make progress and for this purpose the quality of lifelong learning actions is enhanced, intensified and upgraded (European Commission/EACEA/ Eurydice, 2019). Nevertheless, many Adult Education theorists (Knowles, 1998; Jarvis, 2004; Rogers, 2002) believe that the learners of Vocational Training Institutes belong to the "gray zone" in terms of adulthood and that only if they share the characteristics of maturity, self-determination, responsibility, autonomy and self-management, ought to be trained according to the principles of Adult Education. Based on the above considerations, this study focused on whether studying in a public Vocational Training Institute or a University in Lemnos, is related to the attainment of adulthood or has an effect on the students' self-esteem levels.

\section{Method and Data Analysis}

The design for this exploratory study was quantitative descriptive as it measured adulthood scores between two groups of different educational environments and their Self-esteem levels. The study investigates the attainment of adulthood and the students' self-esteem in universities compared to vocational education. Once the central concept of adulthood was examined, the items of maturity, autonomy, self-determination, selfmanagement and, sense of social responsibility have been investigated separately, resulting in making the quantification of the scores easier and ensured full coverage of the central concept of adulthood and its interconnection with self-esteem. The quantitative design had been chosen since the research questions put forward were specific and included the use of quantitative data as well as the gathering of information by a large number of individuals.

For this study, a "convenient sampling was chosen from those to whom the researcher had easy access and they were willing participants" (Cohen, Manion, \& Morrison, 2005, p. 170; Creswell, 2011, p. 182; Robson, 2002, p. 314). The sample of the target population consists 
of two groups, a group of students from the University of the Aegean (Department of Food and Nutrition Sciences) and a group of students of the Public Vocational Training Institute. The Department of Food Science and Nutrition of the University of the Aegean is the only University on the island of Lemnos; it was founded in October 2009 and each year 100 students are admitted to the Department (by decision of the Ministry of Education), of which approximately 70-80 students per year are actively attending the courses. Specifically, the participants of this study were 143 University students compared with 65 Vocational Training students, of whom 38\% were men and $62 \%$ women.

For the purposes of this quantitative survey and the collection of the data, a questionnaire that uses Likert-type response scale and Rosenberg's Self-esteem scale were employed to gather specific information about the attainment of adulthood, and Self-esteem of the University and Vocational Training students. It was decided to employ quantitative instrumentation rather than qualitative due to time constraints and faster data retrieval. While interviews are very easy to carry out, time-consuming data retrieval periods are required as opposed to questionnaires.

Morris Rosenberg's (1965) measurement scale of Self-esteem (RSE) was used to measure the degree of Self-esteem. Regarding the credibility and validity of this tool, there are plenty of researches that confirm it (Baumeister, Campbell, J. D., Krueger, \& Vohs, 2003; Ciarrochi, Heaven, \& Fiona, 2007). Although Rosenberg's Self-esteem scale $(1965,1986)$ was developed on an initial sample consisting of high school students of ten randomly selected schools in the State of New York, it applies to adult learners worldwide and measures global Self-esteem. Rosenberg's Self-esteem scale has four answer grades (I fully agree, agree, totally disagree, disagree) and 10 questions to which the learner is asked to answer. Half of the questions are wording positively, that is, high Self-esteem, and they relate to statements like: "I feel like I have quite good characteristics as a person". The other half have a negative formulation and measure the low Self-esteem and relate to press statements: "sometimes I think I'm not good at all" (Papadopoulou, 2013).

Overall, data from 208 students were processed, (79 male and 129 female participants) with SPSS (Statistical Package for Social Sciences) v22. The significance level was set at 5\% and the statistical analysis of data was based on Descriptive Statistics since it helps the researcher to describe the answers to each question "in a database as well as to identify general trends and the distribution of data" (Creswell, 2011, p. 688). Statistical analysis of the data used the Kolmogorov Smirnov test to check the regularity of the variables. For correlations, the non-parametric Mann-Whitney control for abnormal variables and t-test for those who follow a normal distribution were used. The Pearson $r$ correlation coefficient was used to test the possible correlation between the Rosenberg Self-esteem scale and adulthood. Variables were created to measure the total score each learner received in relation to the questions. As independent variables, the gender and age of students were defined and their effect on the dependent variables related to their attitudes towards the five parameters of adulthood and self-esteem was investigated. In addition, the participants received a score based on the answer given to each question, 
thus creating an overall adulthood variable, summing up the aggregate score of each group's axes (sum of maturity, responsibility, autonomy, self-management and social responsibility).

\section{Findings and Discussion}

A Pearson $r$ correlation coefficient analysis revealed, that there was no statistically significant correlation $(\mathrm{p}=0.619),(\mathrm{p}>0.05)$ between adulthood and self-esteem.

Moreover, the nonparametric Kolmogorov Smirnov test was applied to check the regularity of the constant variables of self-esteem, maturity, responsibility, autonomy, self-management, and social responsibility. The test, as indicated in tables 1 and 2, showed that only the variable of autonomy $(p=0.085)$ and the Rosenberg Self-esteem scale $(p=0.088)$ followed a normal distribution at a $5 \%$ significance level $(p>0.05)$.

As far as gender is concerned, in women Kolmogorov Smirnov's test revealed that all variables met the normality criterion $(p>0.05)$ except for the social responsibility variable $(\mathrm{p}=0.001)$

It is noteworthy, as illustrated in Table 1, that for women, there is a statistically significant difference between Rosenberg's Self-esteem scale and Educational Institute ( $p$ $=0.023)(p<0.05)$. This means that the average rate of Self-esteem in women attending the University of Lemnos is lower than that in women studying in the public Vocational Training Institute.

Table 1: Independent Samples Test for equality of means on self-esteem scale in women

\begin{tabular}{|l|l|c|c|c|}
\hline \multicolumn{2}{|c|}{} & \multicolumn{3}{|c|}{ t-test for Equality of Means } \\
\cline { 3 - 5 } \multicolumn{2}{|c|}{} & df & $\begin{array}{c}\text { Sig. } \\
\text { (2-tailed) }\end{array}$ & $\begin{array}{c}\text { Mean } \\
\text { Difference }\end{array}$ \\
\hline $\begin{array}{l}\text { Self-esteem Scale } \\
\text { (Rosenberg) }\end{array}$ & Equal variances assumed & 127 &, 023 & 2,13925 \\
\cline { 2 - 5 } & Equal variances not assumed & 68,971 &, 022 & 2,13925 \\
\hline
\end{tabular}

However, the findings, as shown in Table 2, concerning the variables of adulthood and the Educational Institute did not demonstrate any statistically significant correlation $(\mathrm{p}=$ $0.536)(p>0.05)$ in men.

Table 2: Independent Samples Test for equality of means on adulthood in men

\begin{tabular}{|l|l|c|c|c|}
\hline \multicolumn{2}{|c|}{} & \multicolumn{3}{|c|}{ t-test for Equality of Means } \\
\cline { 3 - 5 } \multicolumn{2}{|c|}{} & $\begin{array}{c}\text { Sig. } \\
\text { (2-tailed) }\end{array}$ & $\begin{array}{c}\text { Mean } \\
\text { Difference }\end{array}$ & $\begin{array}{c}\text { Std. Error } \\
\text { Difference }\end{array}$ \\
\hline \multirow{2}{*}{ Adulthood } & Equal variances assumed &, 536 & 1,04342 & 1,67894 \\
\cline { 2 - 5 } & Equal variances not assumed &, 570 & 1,04342 & 1,82162 \\
\hline
\end{tabular}

Finally, the findings indicated that there was no statistically significant correlation between the variables of adulthood and the Educational Institute with regards to the overall number of participants $(\mathrm{p}=0.975)$

Table 3: Independent Samples Test for equality of means on adulthood for the whole sample 


\begin{tabular}{|l|l|c|c|c|}
\hline \hline \multicolumn{2}{|c|}{} & \multicolumn{3}{|c|}{ t-test for Equality of Means } \\
\cline { 3 - 5 } \multicolumn{2}{|c|}{} & $\begin{array}{c}\text { Sig. } \\
\text { (2-tailed) }\end{array}$ & $\begin{array}{c}\text { Mean } \\
\text { Difference }\end{array}$ & $\begin{array}{c}\text { Std. Error } \\
\text { Difference }\end{array}$ \\
\hline \multirow{2}{*}{ Adulthood } & Equal variance assumed &, 971 &, 03497 &, 97685 \\
\cline { 2 - 5 } & Equal variance not assumed &, 975 &, 03497 & 1,11581 \\
\hline
\end{tabular}

As for the age factor, the minimum value was 18 years while the maximum was 47 , the mean was 21 years with a standard deviation of 4.5 years. The findings reveal that University students of both sexes are endowed with a combination of knowledge and skills that allow them to express themselves autonomously and to be self-directed and goal-oriented (Browder, Wood, Test, Algozzine, \& Karvonen, 2001) in comparison with the Vocational Training Institute students in Lemnos. Nevertheless, the students of the Vocational Training Institute demonstrated higher levels of maturity than the University students and thus, were able to widely apply the knowledge of the socio-cultural environment in their interactions with others. The mean score of maturity (17.73) of Vocational Institute students $(S D=3.16)$ is statistically significantly higher than that of University students (17.02) $(\mathrm{SD}=2.41)$.

Yet, the same students of Vocational Training seemed to have fewer selfmanagement skills compared to the University students, which showed a higher ability to actively determining the conditions and the parameters of their lives. Their mean score (11.55) $(\mathrm{SD}=2.79)$ is statistically significantly lower than the score of University students (12.65) $(\mathrm{SD}=2.17)$.

With relation to the research question that examines the adulthood-self-esteem correlation of the overall sample, it is noteworthy that the coefficient of self-esteem does not affect adulthood ( $p=0.619),(p>0.05)$.

In addition, the correlation between adulthood and Educational Institute, selfesteem and Educational Institute, in both sexes is not significant when it comes to men. On the contrary, in women, a significant relationship has emerged between Self-esteem and the Educational Institute (Merriam et al., 2007). In particular, the findings have shown that female students of the University of Lemnos have lower Self-esteem than the female students of the Vocational Training Institute on the island. Notably, the mean score of Self-esteem of female University students (19.23) (SD=4.81) is statistically significantly lower than that of female Vocational students (21.37) (SD=4.63).

This may be linked to the fact that the social skills of University students have not yet been fully formed compared to the Vocational Training Institute students who have gained valuable social experience (Caulfield \& Woods, 2013). It is worth mentioning that with regard to the degree of Self-esteem and the axes of adulthood, women appeared to have higher educational and social demands compared to men whose self-esteem and adulthood criteria did not seem to be affected by the Educational Institute $(p=0.333),(p>$ $0.05)$. 
Table 4: Correlations between Self-esteem and Adulthood within men

\begin{tabular}{|l|l|c|c|}
\hline \multicolumn{2}{|c|}{} & Self-esteem Scale (Rosenberg) & Adulthood \\
\hline \multirow{4}{*}{ Self-esteem Scale (Rosenberg) } & Pearson Correlation & 1 &,- 110 \\
\cline { 2 - 4 } & Sig. (2-tailed) & &, 333 \\
\cline { 2 - 4 } & $\mathrm{N}$ & 79 & 79 \\
\hline \multirow{3}{*}{ Adulthood } & Pearson Correlation &,- 110 & 1 \\
\cline { 2 - 4 } & Sig. (2-tailed) &, 333 & 79 \\
\cline { 2 - 4 } & $\mathrm{N}$ & 79 & \\
\hline
\end{tabular}

In this study, the overall scores indicated that there is no significant correlation between adulthood and the Educational Institute as well as between the Educational Institute and self-esteem. However, the results revealed that there are differences between Tertiary Education students and Vocational Institute students in the attainment of specific axes of adulthood. Specifically, the students of the public Vocational Training Institute show higher levels of maturity compared to the University students, yet University students demonstrate higher levels of self-management compared to the students of the public Vocational Training Institute in Lemnos. As Kokkos (2005) contends, the concept of selfmanagement is interwoven with adulthood, and the path to adulthood is only a "continuous effort for integration and a movement toward ever greater self-management and selfdetermination" (p. 41).

\section{Conclusion}

The results of this study revealed that the overall sample of university students acquire a higher degree of social-cognitive self-management skills (Lauermann \& Karabenick, 2013), compared to the overall sample of vocational students. University students' higher levels of commitment to achieving their goals compared to vocational students are strictly related to motivation as it requires action on the part of the individual, cognitive processes to achieve their goals and persistence (Hodkinson, Biesta, \& James, 2008; Kasworm, Rose \& Ross-Gordon, 2017). The concepts of self-determination and selfmanagement are inextricably linked to the characteristics of the self-realization that the overall sample of university students demonstrates and more specifically female students, such as creativity, morality, spontaneity, problem-solving, acceptance and lack of prejudice (Weinstein, Ryan, \& Deci, 2012).

However, vocational students demonstrated higher levels of maturity than the sample of university students and thus, were able to fairly separate emotions from their experiences, by widely using the knowledge of the socio-cultural environment in their interactions with others compared to the students of the University of Lemnos. It is noteworthy that with regard to the degree of self-esteem and the items of adulthood, women appeared to have higher educational and social demands of themselves in relation to men whose self-esteem and adulthood criteria are not affected by their gender or choice of educational institute. However, when it comes to the correlation of the overall adulthood variable and the choice of Educational Institute, the study concludes that this 
choice is not gender-based and does not significantly influence students' adulthood attainment.

It is worth noting that the findings were closely linked to those of researchers who argue that both adulthood and self-esteem are influenced not only by the learning process but also by their environment, experiences, social and cultural contexts (Di Nauta, Merola, Caputo, \& Evangelista, 2018; Janusz \& Walkiewicz, 2018).

In future studies, it would be interesting to investigate the socio-cultural context of the University and Vocational Training Institute students and its impact on the attainment of adulthood and self-esteem in line with the challenges posed by the current social emphasis on self-directed and lifelong learning (Di Nauta, Merola, Caputo, \& Evangelista, 2018). The island of Lemnos can be considered a rather remote decentralized island whose vocational students compared to the university ones often come from a socio-economically disadvantage background and not only they are less likely to aspire to higher education studies, but they are also more prone to dropping out, thereby reinforcing inequality (OECD, 2008; Brock, 2010). Finally, while the cultural scenarios of the life course change and evolve, students' desire for stability and security and yet the striving for change, seem to remain current (Janusz \& Walkiewicz, 2018). In conclusion, the results of this study aimed to be the starting point for a more in-depth exploration of the subject by future researchers.

\section{Acknowledgements}

This article would not have been possible without the advice and support of Professor Eugenia Arvanitis. Dr. Eugenia Arvanitis is an Associate Professor of Interculturality \& Diversity in Education at the University of Patras, Greece. Her expertise also includes assessing new learning and book editing. She has edited three books namely Zac Vogiazopoulos's (2006) book (Bonegilla: Memories and Recollections of an Insider), Mary Kalantzis \& Bill Cope (2013) book New Learning: Basic Elements of the Science of Education and in collaboration with Achilles Kameas the book Intercultural Mediation in Europe: Narratives of Professional Transformation (http://ondiversity.cgpublisher.com/product/pub.190/prod.25). She provided insight and expertise that greatly assisted the development of the research. I feel fortunate to have received her outstanding mentorship in every stage of the research.

\section{Conflict of Interest Statement}

The authors declare no conflicts of interests.

\section{About the Authors}

Arvanitidou Sofia (sofia.arvanitidou@gmail.com) is the Deputy Director of the Vocational Training Institute on the island of Lemnos, Greece. She also holds two master's degrees, one in Translation Studies and another in Education. Her research interests currently include learner autonomy, information and communications Technology (ICT) in Adult Education, second language acquisition and intercultural 
communication (publication in the online journal of the Centre for Communication, Media and Society, University of Kwazulu-Natal, South Africa, SUBtext No: 16, Winter 2011 Cultural Mapping of the Northern Cape. page 10 - 11. http://ccms.ukzn.ac.za/)

Dr. Eugenia Arvanitis (earvanitis@upatras.gr) is an Associate Professor of Interculturality \& Diversity in Education at the University of Patras, Greece. Her Ph.D. research involved an in depth analysis of teaching practices and educational policies in Australia in the late 1990s with particular emphasis on Greek language classes and afterhours schools in Victoria. She teaches at the Language Education for Refugees and Migrants (LRM) https://www.eap.gr/el/programmata-spoudwn/394-languageeducation-for-refugees-and-migrants-1rm/4530-language-education-for-refugees-andmigrants-lrm of the Hellenic Open University.

\section{References}

Bandura, A. (1997). Self-Efficacy: The exercise of control. USA: Freeman \& Company.

Bowman, N. (2010b). Can 1st Year College Students Accurately report their Learning and Development? American Educational Research Journal, Vol. 47(2), 466-496.

Bradberry, T., \& Greaves, J. (2003). Emotional intelligence quick book: Everything you need to know. San Diego, CA: Talent Smart Inc.

Brock, T. (2010).Young Adults and Higher Education: Barriers and Breakthroughs to Success. Future of Children, Vol. 20(1), Princeton, pp. 109-132

Browder, D., Wood, W. M., Test, D. W., Algozzine, B., \& Karvonen, M. R. (2001). A map for teachers to follow in reviewing resources on self-determination. Remedial and Special Education, 22, 233-244.

Carson, R. L., \& Domangue, E. A. (2013). The emotional component of service-learning. Journal of Experiential Education, 36(2)

Caulfield, J., \& Woods, T. (2013). Experiential learning: Exploring its long-term impact on socially responsible behavior. Journal of Scholarship of Teaching and Learning, 13(2), 31-48.

Cedefop. (2014a).Vocational education and training in Greece. Luxembourg: Publications Office of the European Union.

Cedefop. (2018). Apprenticeship review: Greece. Modernising and expanding apprenticeships in Greece. Luxembourg: Publications Office. Thematic country reviews

Cedefop. (2019). Understanding of Apprenticeships in the National Context. Retrieved March 13, 2020 from https://www.cedefop.europa.eu/en/publications-andresources/data-visualisations/apprenticeship-schemes/country-fiches/greece/

Christodoulou, A. (2011). UNESCO values in 21st century education, In N. Perraki (Ed.), Retrieved March 13, 2016 from http://nata.webpages.auth.gr/

Ciarrochi, J., Heaven, P. C. L., \& Fiona, D. (2007). The impact of hope, self-esteem, and attributional style on adolescents' school grades and emotional well-being: A longitudinal study. Journal of Research in Personality,41, 1161-1178. 
Cohen, L. and Manion, L. (2005) Research Methods in Education (fifth edition). London: Routledge.

Council of the European Union. (2012). Council recommendation of 20 December 2012 on the validation of non-formal and informal learning. Official Journal of the European Union, C 398, 22.12.2012, pp. 1-5.

Creswell, J. W., \& Clark, V. L. P. (2011). Designing and conducting mixed methods research (2nd ed.). Thousand Oaks, CA: Sage Publications.

Czabanowska, K., Moust, J., Meijer, A., Schroder-Back, P., \& Roebertsen, H. (2012). Problem-based learning revisited, introduction of active and self-directed learning to reduce fatigue among students. Journal of University Teaching and Learning Practice, 9(1), 1-13.

DelleFave, A., Wissing, M., Brdar, I., Vella-Brodrick, D., \& Freire, T. (2013). Cross-cultural perceptions of meaning and goals in adulthood: Their roots and relations with happiness. In A. S. Waterman (Ed.), The best within us: Positive psychology perspectives on eudaimonia (pp. 227-247). American Psychological Association. https://doi.org/10.1037/14092-012

Di Nauta P., Merola B., Caputo F., \& Evangelista F (2018). Reflections on the role of university to face the challenges of knowledge society for the local economic development. Journal of the Knowledge of the Economy, 9(1):180-198. doi: 10.1007/s13132-015-0333-9.

EOPPEP (2016). Greece EQF Referencing Report. Retrieved January 17, 2019 from: http://www.opengov.gr/ypepth/

European Commission. (2004c). Implementation of «Education and Training 2010» - Work Programme-Key Competences and Lifelong Learning: A European Reference Framework. Progress Report Working Group B, November 2004.

European Commission. (2009). Key Data on Education in Europe. Retrieved March 17, 2019 from: http://www.opengov.gr/ypepth/

European Commission. (2018). Education and Training Monitor 2018 Greece. Luxembourg: Publications Office of the European Union. Retrieved from https://ec.europa.eu/education/sites/education/files/document-librarydocs/et-monitor-report-2018-greece en.pdf

European Commission. (2019). Key competences for lifelong learning. Retrieved from https://op.europa.eu/en/publication-detail/-/publication/297a33c8-a1f311e9-9d01-01aa75ed71a1/language-en

European Commission/EACEA /Eurydice. (2019). Higher Education. Retrieved January 7, 2020 from: https://eacea.ec.europa.eu/national-policies/eurydice/content/highereducation-33 en

European Commission/EACEA/Eurydice. (2015). Adult Education and Training in Europe: Widening Access to Learning Opportunities. Eurydice Report. Luxembourg: Publications Office of the European Union 
European Council (2018). Recommendation on a European framework for quality and effective apprenticeships. 2017/0244 (NLE). Retrieved March 11, 2019 from: http://data.consilium.europa.eu/doc/document/ST-6779-2018-INIT/en/pdf

Foundation for Economic and Industrial Research (IOBE), (2018). Eк $\pi \alpha i \delta \varepsilon v \sigma \eta \kappa \alpha \iota \alpha \gamma o \rho \alpha ́$

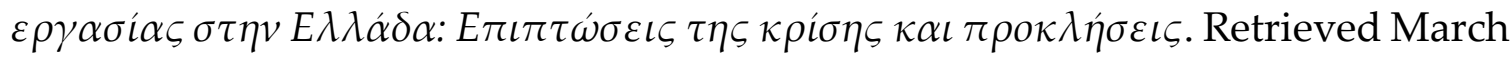
3, 2019 from http://iobe.gr/docs/research/RES 05 F 09072018 REP.pdf.

Freire, P. (1982). Education for critical consciousness. New York: The continuum Publishing Corporation.

Freire, P. (2000). Pedagogy of the oppressed (30th anniversary ed.). New York: Continuum. General Secretariat for Lifelong Learning (2013).Vocational Training. Retrieved March 19, 201 from http://www.gsae.edu.gr/el/epaggelmatiki-katartisi/

Gonçalves, S. (2011) Intangible culture, cooperation and intercultural dialogue among university students. Intercultural Education, 22:1, 8395, doi: $\underline{10.1080 / 14675986.2011 .549647}$

Gorsky, P., Caspi, A. \& Tuvi-Arad, I. (2004). Use of Instructional Dialogue by University Students in a Distance Education Chemistry Course. In L. Cantoni \& C. McLoughlin (Eds.), Proceedings of ED-MEDIA 2004--World Conference on Educational Multimedia, Hypermedia \& Telecommunications (pp. 3568-3574). Lugano, Switzerland: Association for the Advancement of Computing in Education (AACE). Retrieved April 17 , 2020 from https://www.learntechlib.org/primary/p/12029/.

Halx, M. D. (2010). Reconceptualizing college and university teaching through the lens of adult education: regarding undergraduates as adults. Teaching in Higher Education, 15(5), 519-530.

Hodkinson, P., Biesta, G., and James, D. (2008). Understanding learning culturally: Overcoming the dualism between social and individual views of learning. Vocations and Learning, 1, 27-47.

Janusz, B. and Walkiewicz, M. (2018). The Rites of Passage Framework as a Matrix of Transgression Processes in the Life Course, Journal of Adult Development 25, 151159.

Jarvis, P. (1983). Adult and Continuing Education, London: Croom Helm.

Jarvis, P. (2004). Adult Education and Lifelong Learning: Theory and Practice, (3rd ed.). London: Falmer Press.

Kalantzis, M., \& Cope, B. (2005). Learning by Design. Melbourne: Victorian Schools Innovation Commission.

Kaliris, A., \& Sidiropoulou-Dimakakou, D. (2012, November). Self-efficacy beliefs and specialized competencies of human resources management executives and career counselors working in enterprises: Their indirect role in the confrontation of the crisis. Paper presented at the 4th Panhellenic Conference of Counseling Psychology (14/11), Hellenic Psychological Association (ELPSE) - Counseling Psychology Sector, Aristotle University of Thessaloniki (AUT), Thessaloniki, Greece. 
Kasworm, C. E., Rose, A. D., \& Ross-Gordon, J. M. (Eds.) (2010). Handbook of adult and continuing education. Thousand Oaks, CA: Sage Publications.

Knowles, M. (1990). The Adult Learner: A Neglected Species (4 $4^{\text {th }}$ ed.). Houston, TX.: Gulf Publishing.

Knowles, M. (1998). The Adult Learner. Houston, Texas: Gulf.

Knowles, M. S., Holton, E. F., \& Swanson, R. A. (2015). The adult learner: The definitive classic in adult education and human resource development (8th ed.). Burlington, MA: Elsevier.

Kokkos, A. (2005) Adult Education: Investigating the domain. Athens: Metaichmio.

Kreber, C. (2009). Supporting Student Learning in the Context of Diversity, Complexity and Uncertainty. In C. Kreber (Ed.), The University and its Disciplines: Teaching and Learning Within and Beyond Disciplinary Boundaries. New York and London: Routledge.

Krems, J. A., Kenrick, D., \& Neel, R. (2017). Individual Perceptions of Self-Actualization: What Functional Motives Are Linked to Fulfilling One's Full Potential? Personality and Social Psychology Bulletin, 43(9), 13371352. https://doi.org/10.1177/0146167217713191

Lauermann, F., \& Karabenick, S. A. (2013). The meaning and measure of teachers' sense of responsibility for educational Outcomes. Teaching and Teacher Education, 30, 1326.

Maslow, A. (1943). A Theory of Human Motivation. Psychological Review, 50(4), 370-396.

Merriam, S. B., Caffarella, R. S., \& Baumgartner, L. M. (2007). Learning in adulthood: A comprehensive guide. San Francisco, CA: Jossey-Bass.

Merriam, S. B., \& Bierema, L. L. (2014). Adult learning: Linking theory and practice. San Francisco: Jossey-Bass.

Mezirow, J. (1991). Transformative Dimensions of Adult Learning. San Francisco: JosseyBass.

Mikkonen, S., Pylväs, L., Rintala, H., Nokelainen, P., \& Postareff, L. (2017). Guiding workplace learning in vocational education and training: A literature review. Empirical Research in Vocational Education and Training, 9(9), 1-22.

Monahan, K. C., Steinberg, L., Cauffman, E., \& Mulvey, E. P. (2009). Trajectories of antisocial behavior and psychosocial maturity from adolescence to young adulthood. Developmental Psychology, 45(6), 16541668. https://doi.org/10.1037/a0015862

OECD. (2008). Tertiary Education for the Knowledge Society, OECD Publishing, Paris. Retrieved from: www.oecd.org/edu/tertiary/review/

OECD. (2017a). Reform Agenda for 2017: Overview and Country Notes. Retrieved from http://www.oecd.org/economy/growth/Going-for-Growth-Greece-2017.pdf

OECD. (2007). Human Capital: How what you know shapes your life. Retrieved from https://www.oecd.org/insights/

Organisation for Economic Co-operation and Development (OECD). (2010). Educating Teachers for Diversity. Meeting the Challenge. Paris: OECD. 
Organisation for Economic Co-operation and Development (OECD). (2014b). Testing student and university performance globally: OECD's AHELO. OECD: Skills beyond school. Paris: OECD Publishing. Retrieved from http://www.oecd.org/edu/skills-beyond-school/

Papadopoulou, E. (2013). Self-esteem and satisfaction with life of deaf and hard-of-hearing Adults. (Thesis) .University of Macedonia, Department of Educational and Social Policy: Thessaloniki. Retrieved from https://dspace.lib.uom.gr/bitstream/2159/15932/6/PapadopoulouEleniMsc2013.pd $\underline{\mathrm{f}}$

Rintala, H., \& Nokelainen, P. (2020). Vocational Education and Learners' Experienced Workplace Curriculum. Vocations and Learning, 13,113-130. https://doi.org/10.1007/s12186-019-09229-w

Robson, C. (2002).Real world research: A resource for social scientists and practitionerresearchers. Oxford, UK: Blackwell.

Rogers, A. (2002). Teaching adults. Open University Press: Buckingham, Philadelphia.

Rogers, J. (1971). Adults Learning, The Open University Press: Buckingham.

Rogers, R. R. (2001). Reflection in Higher Education: A Concept Analysis. Innovative Higher Education, 26 (1), 37-57.

Rosen, J. A., Glennie, E. J., Dalton, B. W., Lennon, J. M., \& Bozick, R. N. (2010). Noncognitive Skills in the Classroom: New Perspectives on Educational Research. RTI Press. Retrieved from www.rti.org/pubs/bk-0004-1009-rosen.pdf

Rosenberg, M. (1965). Society and the Adolescent Self-Image. Princeton, NJ: Princeton University Press.

Rosenberg, M. (1986). Conceiving the Self. Malabar, FL: Robert E. Krieger.

Ross-Gordon, J., Rose, A. D., \& Kasworm, C. E. (2017). Foundations of adult and continuing education. San Francisco, CA: Jossey-Bass.

Strong, R., Wynn, J. T., Irby, T. L., \& Lindner, J. R. (2013). The relationship between students' leadership style and self-directed learning level. Journal of Agricultural Education, 54(2), 174-185. doi:10.5032/jae.2013.02174

Taylor, P., \& Pettit, J. (2007). Learning and teaching participation through action research: Experiences from an innovative masters programme. Action Research, 5, 231-247.

Tight, M. (2002). Key Concepts in Adult Education and Training. London: Routledge.

Tynjälä, P. (2013). Toward a 3-P model of workplace learning: a literature review. Vocations and Learning, 6(1), 11-36.

UNESCO and Commonwealth of Learning. (2011). Guidelines for open educational resources $(O E R)$ in higher education. Paris: UNESCO.

Wang, V., Bain, B., Hansman, C., \& Hope, J. (2017). Educational leadership and organizational management. Charlotte, NC: Information Age Publishing.

Weinstein, N., Ryan, R. M., \& Deci, E. L. (2012). Motivation, meaning and wellness: A self-determination perspective on the creation and internalization of personal meanings and life goals. In P. T. P. Wang (Ed.), The human quest for meaning: 
Theories, research, and applications (pp. 81-106). New York: Routledge Publishers. doi: $\underline{10.4324 / 9780203146286}$ be applied to their work. Under the terms of this license, no permission is required from the author(s) or publisher for members of the community to copy, distribute, transmit or adapt the article content, providing a proper, prominent and unambiguous attribution to the authors in a manner that makes clear that the materials are being reused under permission of a Creative Commons License. Views, opinions and conclusions expressed in this research article are views, opinions and conclusions of the author(s). Open Access Publishing Group and European Journal of Alternative Education Studies shall not be responsible or answerable for any loss, damage or liability caused in relation to/arising out of conflict of interests, copyright violations and inappropriate or inaccurate use of any kind content related or integrated on the research work. All the published works are meeting the Open Access Publishing requirements and can be freely accessed, shared, modified, distributed and used in educational, commercial and non-commercial purposes under a Creative Commons Attribution 4.0 International License (CC BY 4.0). 